\title{
Pengaruh Perbandingan Fase Minyak Virgin Coconout Oil (Cocos nucifera L.) dan Lemak Kakao (Theobrama Cacao L.) serta Suhu terhadap Karakteristik Sediaan Krim Effect of Comparison Phase Phase of Virgin Coconout Oil (Cocos nucifera L.) and Cocoa Fat (Theobrama cacao L.) and Temperature on Cream Characteristics
}

\author{
I Kadek Aditya Prasatya, Lutfi Suhendra*, Ni Made Wartini \\ PS Teknologi Industri Pertanian, Fakultas Teknologi Pertanian, Universitas Udayana, Kampus Bukit \\ Jimbaran, Badung, Kode pos : 80361; Telp/Fax : (0361) 701801.
}

Diterima 11 Agustus 2019 / Disetujui 15 Januari 2020

\begin{abstract}
Virgin coconut oil turn into liquid based in a room temperature that has lot of vitamin $E$ and coconut acid. Cocoa butter is solid in temperature that has lot of stearic acid. This research aims to know the temperature effects and comparation of oil phase, virgin coconut oil : cocoa butter in the characteristic of cream based determine the temperature and comparation of oil phase (virgin coconut oil : cocoa butter) to produce cream based. The trial design in this research was the second factorial trial. This reasearch used factorial randomized block. First factorial was the comparation oil phase of virgin coconut oil : cocoa butter consist of 3 levels, that is 1:3,1:5 and 1:7. While in the second factorial the was heating temperatures, consist of 3 levels that is $60 \pm 2^{\circ} \mathrm{C}, 70 \pm 2^{\circ} \mathrm{C}$ and $80 \pm 2^{\circ} \mathrm{C}$. The comparation treatments of oil phase virgin coconut oil : cocoa butter that really affected the viscosity, cohenren power, diameter of spread power and seperation ratio, heating temperature really affected with diameter of spread power and coherent power. Tempererature treatment and comporation of oil phase affected the diameter of spread power. The temperature treatment and oil phase ratio have a very significant effect on the dispersal power. Comparison of VCO and cocoa butter treatment (1:7) with a temperature of $80 \pm 2{ }^{\circ} \mathrm{C}$ is the best treatment to produce cream preparations with characteristics of a homogeneous cream, viscosity (46.000 cp), cohenren power (9,77 seconds), diameter of spread power $(7,075 \mathrm{~cm})$, separator ratio $(0,27 \mathrm{~cm})$ and $\mathrm{pH}(6,65)$.
\end{abstract}

Keywords: Virgin coconut oil, cocoa butter, temperature, characteristic, based cream.

\begin{abstract}
ABSTRAK
Virgin coconut oil bersifat cair pada suhu ruang dan kaya dengan kandungan vitamin E dan asam laurat. Lemak kakao bersifat padat pada suhu ruang dan kaya akan kandungan asam stearat. Penelitian ini bertujuan untuk mengetahui pengaruh suhu dan perbandingan fase minyak (virgin coconut oil dan lemak kakao) terhadap karakteristik sediaan krim dan menentukan suhu dan perbandingan fase minyak (virgin coconut oil : lemak kakao) terbaik untuk menghasilkan sediaan krim. Percobaan dalam penelitian ini adalah percobaan faktorial 2 faktor menggunakan Rancangan Acak Kelompok. Faktor I yaitu perbandingan fase minyak VCO : lemak kakao terdiri atas 3 taraf yaitu 1:3, 1:5, dan 1:7. Sedangkan faktor II yaitu suhu pemanasan terdiri dari 3 taraf diantaranya $60 \pm 2^{\circ} \mathrm{C}, 70 \pm 2^{\circ} \mathrm{C}$, dan $80 \pm 2^{\circ} \mathrm{C}$. Perlakuan perbandingan fase minyak VCO : lemak kakao berpengaruh sangat nyata terhadap viskositas, daya
\end{abstract}

\footnotetext{
*Korespondensi Penulis:

Email : lutfi_s@unud.ac.id
} 
lekat, daya sebar dan rasio pemisah, suhu pemanasan berpengaruh sangat nyata terhadap daya sebar dan daya lekat. Perlakuan suhu dan perbandingan fase minyak berpengaruh sangat nyata terhadap daya sebar. Perlakuan perbandingan VCO dan lemak kakao (1:7) dengan suhu $80 \pm 2^{\circ} \mathrm{C}$ merupakan perlakuan terbaik untuk menghasilkan sediaan krim dengan karakteristik krim bersifat homogen, viskositas $(46.000 \mathrm{cp})$, daya lekat $(9,77$ detik), daya sebar $(7,075 \mathrm{~cm})$, rasio pemisah $(0,27 \mathrm{~cm})$ dan $\mathrm{pH}(6,65)$.

Kata kunci: Virgin coconut oil, lemak kakao, suhu, karakteristik, sediaan krim.

\section{PENDAHULUAN}

Krim merupakan salah satu produk kosmetik yang berbentuk semi padat berupa emulsi. Pada umumnya, sediaan krim dibagi menjadi dua fase, yaitu fase minyak dalam air (M/A) dan fase air dalam minyak (A/M). Sediaan fase M/A terdiri dari fase internal berupa tetes-tetes kecil minyak yang terdispersi dalam fase air. Krim cenderung disukai oleh banyak orang karena memiliki sifat nyaman dan memberikan rasa berminyak (Nayank, 2004). Karakteristik krim yang baik memiliki daya tahan yang cukup lama pada permukaan krim sebelum permukaan dibersihkan. Pada saat digunakan, krim memberikan beberapa efek mengkilap, berminyak, lembab, mudah tersebar merata dan mudah berpenetrasi ke dalam kulit (Anwar, 2012). Ada beberapa faktor-faktor yang dapat mempengaruhi proses pembuatan krim, diantaranya faktor bahan baku dan suhu pemanas dalam pembuatan sediaan krim.

Bahan baku yang bisa digunakan dalam pembuatan sediaan krim adalah VCO dan lemak kakao. Virgin coconut oil (VCO) merupakan minyak yang berasal dari olahan buah kelapa. Virgin coconut oil sangat baik digunakan dalam bidang kesehatan yang dipercaya sebagai pencegah penyakit kanker, tekanan darah tinggi, jantung dan lain-lain. Hal ini dikarenakan tingginya kandungan asam lemak tidak jenuh yang sangat bermanfaat bagi kesehatan tubuh manusia (Setiaji and Prayugo, 2006). Menurut penelitian sebelumnya virgin coconout oil kaya akan kandungan asam lemak seperti asam laurat, asam palmitat, asam oleat, dan asam oktadekanoat (Novilla and Nursidika, 2017).
Lemak kakao berasal dari biji kakao yang dapat diolah menjadi beberapa produk. Besarnya kandungan teobromin dalam biji kakao sebanyak 2-3\% (Lecumberri et al., 2007) dapat digunakan untuk merileksasikan serta menimbulkan rasa nyaman. Lemak kakao sangat baik digunakan karena kaya akan vitamin $\mathrm{E}$ dan asam stearat yang bermanfaat bagi kesehatan kulit seperti melembabkan kulit, menjaga kulit dari terik panas sinar matahari sehingga terlihat lebih awet muda dan dapat menangkal radikal bebas karena mengandung tokoferol dan polifenol (Rubiyo, 2012).

VCO mengandung asam laurat $48 \%$ 53\% (Lucida et al., 2008) dan lemak kakao mengandung asam stearat $24,51 \%-31,13 \%$ (Risanti et al.,2010). Perbandingan VCO dan lemak kakao yang tepat akan mempengaruhi karakteristik krim. Pada penelitian sebelumnya oleh Diah et al, (2014) mengenai pengaruh konsentrasi asam stearat terhadap karakteristik sediaan krim dan pelepasan krim kurkumin, hasil terbaik adalah asam stearat 5\% (5gram), penelitian menurut Mu'awanah et al. (2014) tentang pengaruh konsentrasi VCO terhadap stabilitas emulsi kosmetik.

Menurut penelitian Dwiastuti (2009), suhu dalam pembuatan krim merupakan faktor yang paling dominan dalam mempengaruhi karakteristik sediaan krim. Suhu yang tinggi pada saat pembuatan krim dapat mengakibatkan penurunan viskositas krim sehingga krim menjadi semakin encer dan nyaman saat digunakan. Pada proses pembuatan sediaan krim, suhu yang terbaik adalah $60^{\circ} \mathrm{C}-80^{\circ} \mathrm{C}$ (Mitsuki, 1997). Suhu dapat mempengaruhi tegangan antar muka sehingga mempengaruhi sifat fisik krim 
(Nielloud and Mesters, 2000). Oleh karena itu, perlu dilakukan penelitian mengenai pengaruh perbandingan virgin coconout oil (VCO) dan lemak kakao serta suhu terhadap karakterisitik sediaan krim. Penelitian ini bertujuan untuk mengetahui pengaruh perbandingan bahan dan suhu terhadap karakteristik sediaan krim dan menentukan perbandingan bahan dan suhu terbaik untuk menghasilkan sedian krim.

\section{METODE PENELITIAN}

\section{Tempat dan Waktu}

Penelitian ini dilakukan di Laboratorium Rekayasa Proses dan Pengendalian Mutu, Fakultas Teknologi Pertanian, Universitas Udayana. Waktu pelaksanaan penelitian dimulai dari Juni sampai Agustus 2019.

\section{Alat dan Bahan}

Peralatan yang digunakan dalam penelitian ini adalah hot plate (Sigma), timbangan analitik (Shimadzu), viskosimeter (Brokfield), centrifuge (Rotofix 32 Hettich), gelas beker (Pyrex Iwaki Te-32), gelas ukur (Pyrex Iwaki Te-32), pH meter (Beckman), gelas objek, cawan petri (Pyrex Iwaki Te-32), mixer(Philips), tabung reaksi (Pyrex Iwaki Te-32), pipet tetes (Medika), sendok, pisau, mangkok kecil dan lempengan kaca.

Bahan utama yang digunakan dalam penelitian ini adalah virgin coconut oil (VCO
SELUMBUNG), lemak kakao (CAU Chocolates Bali), akuades, xanthan gum (Biotechno), gliserin (Emsure), beeswax (PT. Brataco), tween $80(\mathrm{KGaA})$, dan span 80 (KGaA).

\section{Rancangan Percobaan}

Percobaan ini menggunakan

Rancangan Acak Kelompok (RAK) dengan dua faktor. Faktor I yaitu perbandingan bahan virgin coconout oil dan lemak kakao (B) terdiri atas 3 taraf yaitu $\mathrm{B} 1=1: 3, \mathrm{~B} 2=1: 5$, dan $\mathrm{B} 3=1: 7$. Faktor II yaitu suhu pemanasan $(\mathrm{T})$ terdiri atas 3 taraf yaitu $\mathrm{T} 1=60 \pm 2^{\circ} \mathrm{C}, \mathrm{T} 2=$ $70 \pm 2^{\circ} \mathrm{C}$, dan $\mathrm{T} 3=80 \pm 2^{\circ} \mathrm{C}$.

Dari 2 faktor tersebut diperoleh 9 kombinasi perlakuan, masing-masing perlakuan dikelompokan berdasarkan waktu pelaksaannya sebanyak 2 kelompok sehingga diperoleh 18 unit percobaan. Data obyektif yang diperoleh dianalisis dengan analisis ragam (Analysis of Variant atau ANOVA) dan apabila perlakuan berpengaruh terhadap variabel yang diamati, maka dilanjutkan dengan uji Beda Nyata Jujur (BNJ) menggunakan software minitab 19. Perlakuan terbaik ditentukan dari uji indeks efektivitas (de Garmo et al., 1984).

\section{Pelaksanaan Penelitian}

Pada penelitian ini menggunakan dua fase yaitu fase minyak dan fase air. Formula dalam pembuatan krim dapat dilihat pada Tabel 1.

Tabel 1. Formula krim.

\begin{tabular}{|c|c|c|c|c|c|}
\hline \multirow{2}{*}{ No } & \multirow{2}{*}{ Bahan } & \multicolumn{3}{|c|}{ Formulasi Sediaan Krim $(100 \mathrm{~g})$} & \multirow{2}{*}{ Jumlah } \\
\hline & & B1 & B2 & B3 & \\
\hline 1 & $\mathrm{VCO}$ & 7,5 & 5 & 3,75 & $* *$ \\
\hline 2 & Lemak Kakao & 22,5 & 25 & 26,25 & $* *$ \\
\hline 3 & Twen 80 dan Span 80 & 5 & 5 & 5 & 5 \\
\hline 4 & Beeswax & 15 & 15 & 15 & 15 \\
\hline 5 & Gliserin & 4 & 4 & 4 & 4 \\
\hline 6 & Xanthan Gum & 5 & 5 & 5 & 5 \\
\hline 7 & Aquades & 41 & 41 & 41 & 41 \\
\hline
\end{tabular}

Sumber: Pra Penelitian berdasarkan Hydrophile-Liphopile Balance (2019). 
Pada penelitian ini, bahan dibagi menjadi 2 fase yaitu fase minyak dan fase air. Bahan fase minyak yaitu VCO, lemak kakao, gliserin, beeswax, tween 80, dan span 80 dituangkan ke dalam gelas beker pertama dan bahan-bahan fase air seperti xanthan gum dan akuades dituangkan juga ke gelas beker kedua. Kedua gelas beaker dipanaskan di atas hot plate hingga mencapai suhu sesuai perlakuan $60 \pm 2^{\circ} \mathrm{C}, \quad 70 \pm 2^{\circ} \mathrm{C}$ dan $80 \pm 2^{\circ} \mathrm{C}$ sambil diaduk secara manual agar bahan tercampur dengan baik.

Selanjutnya dilakukannya tahap pencampuran kedua fase. Setelah itu diaduk secara manual di atas hot plate selama 5 menit, setelah 5 menit adonan krim dituangkan ke dalam wadah lalu diaduk kembali dengan mixer selama 10 menit. Krim didiamkan selama 24 jam pada suhu ruang untuk selanjutnya dilakukan pengujian terhadap sampel yang dihasilkan. Diagram alir pembuatan krim dapat dilihat pada Gambar 1.

\section{Variabel yang Diamati}

Variabel yang diamati pada sediaan krim adalah homogenitas (Michael and Ash, 1997), viskositas (Jufri et al., 2006) , daya lekat (Delia et al., 2015), daya sebar (Lestari, 2002), rasio pemisahaan (Smaoui et al., 2012) dan $\mathrm{pH}$ (Iswindari, 2014).

\section{HASIL DAN PEMBAHASAN}

\section{Homogenitas Krim}

Hasil pengamatan menunjukan sediaan krim dari semua perlakuan bersifat homogen, tidak ada butiran-butiran kasar pada krim yang terbentuk. Hasil ini sesuai dengan persyaratan sediaan krim yaitu homogen, tidak terlihatnya dan tidak terasanya butira-butiran kasar (Lubis, 2012). Sediaan krim yang homogen mengidentifikasi bahwa bahan-bahan yang digunakan pada proses pembuatan krim tercampur dengan sangat sempurna. Tidak meratanya sediaan krim dapat berakibat fatal jika sampai digunakan, karena akan dapat melukai permukaan kulit saat dioleskannya krim pada kulit. Sediaan krim yang bersifat homogen dapat dilihat pada Gambar 2.

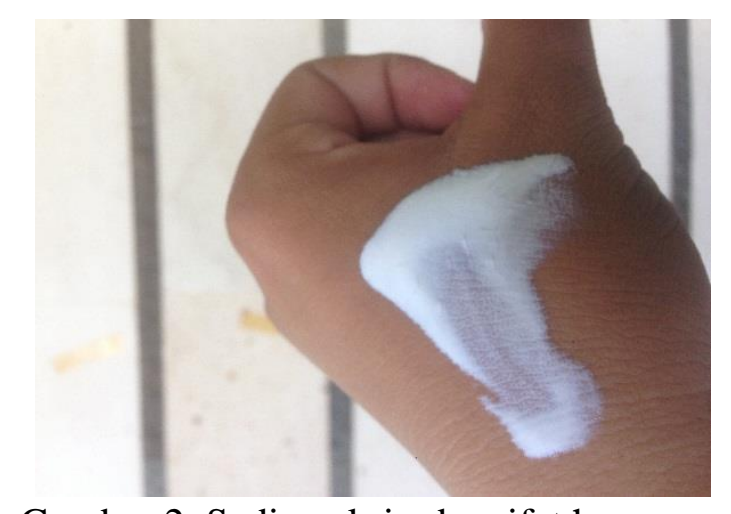

Gambar 2. Sediaan krim bersifat homogen

\section{Viskositas}

Hasil analisis menunjukkan perlakuan perbandingan fase minyak antara VCO dan lemak kakao serta suhu berpengaruh sangat nyata $(p \leq 0,01)$, sedangkan interaksi kedua perlakuan berpengaruh tidak nyata $(p>0,05)$ terhadap uji viskositas sediaan krim. Nilai rata-rata dapat dilihat pada Tabel 2 .

Tabel 2. Nilai rata-rata viskositas (cp) sediaan krim pada perlakuan perbandingan fase minyak VCO dan lemak kakao serta suhu.

\begin{tabular}{ccccc}
\hline Perbandingan & \multicolumn{3}{c}{ Suhu $\left({ }^{\circ} \mathrm{C}\right)$} & Rata- rata \\
\cline { 2 - 4 } $\begin{array}{c}\text { Bahan(VCO\&Lemak } \\
\text { Kakao) }\end{array}$ & $60 \pm 2$ & $70 \pm 2$ & $80 \pm 2$ & \\
\hline$(1: 3)$ & $32.000 \pm 0,00$ & $34.000 \pm 2.828$ & $38.000 \pm 2.828$ & $34.666,7 \pm 3.266^{\mathrm{a}}$ \\
$(1: 5)$ & $34.000 \pm 2.828$ & $38.000 \pm 2.828$ & $40.000 \pm 6.570$ & $37.333,3 \pm 4.131^{\mathrm{b}}$ \\
$(1: 7)$ & $42.000 \pm 2.828$ & $42.000 \pm 2.828$ & $46.000 \pm 2.828$ & $43.333,3 \pm 3.011^{\mathrm{a}}$ \\
\hline Rata-rata & $36.000 \pm 5.060^{\mathrm{b}}$ & $38.000 \pm 4.195^{\mathrm{ab}}$ & $41.333,3 \pm 4.844^{\mathrm{a}}$ & \\
\hline
\end{tabular}


Keterangan: Huruf yang berbeda di belakang nilai rata-rata rata pada baris atau kolom yang sama menunjukkan perbedaan nyata $(\mathrm{p} \leq 0,05)$. Data merupakan rata-rata dari dua kelompok percobaan.

Tabel 2 menjelaskan bahwa semakin banyak lemak kakao dalam perbandingan bahan maka semakin tinggi nilai viskositas yang didapat, hal ini dikarenakan penambahan lemak kakao yang meningkat dan jumlah VCO yang menurun. Menurut penelitian Nugraha (2015) dinyatakan lemak yang memiliki bobot molekul asam lemak kecil misalnya asam laurat akan menghasilkan krim lebih encer dibandingkan krim yang dibuat dari bahan dengan asam lemak yang memiliki bobot molekul besar misalnya asam stearat. Kandungan asam stearat pada lemak kakao bersifat padat pada suhu ruang, sehingga menyebabkan semakin banyak jumlah lemak kakao pada fase minyak maka akan menghasilkan nilai viskositas yang tinggi (Risanti et al.,2010).

Semakin tinggi suhu pada pemanasan mengakibatkan nilai viskositas sediaan krim meningkat, hal ini dikarenakan suhu yang tinggi dapat mempercepat penguapan air dalam proses pencampuran bahan. Suhu yang baik pada proses pencampuran bahan krim berkisar antara $60^{\circ} \mathrm{C}-80^{\circ} \mathrm{C}$ ( Mitsuki, 1997). Nilai pada uji viskositas masih memenuhi standar, nilai standar viskositas berkisar antara 2.000 sampai $50.000 \mathrm{cp}$ (SNI, 1996).

\section{Daya lekat}

Berdasarkan hasil analisis keragaman bahwa perbandingan fase minyak antara VCO dan lemak kakao serta suhu berpengaruh sangat nyata $(\mathrm{P} \leq 0,01)$, sedangkan interaksinya kedua perlakuan berpengaruh tidak nyata $(\mathrm{P}>0,05)$ terhadap uji daya lekat sediaan krim. Nilai rata-rata uji daya lekat dapat dilihat pada Tabel 3.

Tabel 3. Nilai rata-rata daya lekat (detik) sediaan krim pada perlakuan perbandingan fase minyak VCO dan lemak kakao serta suhu.

\begin{tabular}{ccccc}
\hline & \multicolumn{3}{c}{ Suhu $\left({ }^{\circ} \mathrm{C}\right)$} & \multirow{2}{*}{ Rata- rata } \\
\cline { 2 - 4 } Perbandingan Bahan & \multirow{2}{*}{$60 \pm 2$} & $70 \pm 2$ & $80 \pm 2$ & \\
\hline$(1: 3)$ & $4,620 \pm 0,19$ & $6,505 \pm 0,10$ & $6,520 \pm 0,06$ & $5,882 \pm 0,98^{\mathrm{c}}$ \\
$(1: 5)$ & $7,410 \pm 0,66$ & $7,995 \pm 0,16$ & $8,460 \pm 0,04$ & $7,955 \pm 0,56^{\mathrm{b}}$ \\
$(1: 7)$ & $7,450 \pm 0,31$ & $8,295 \pm 0,03$ & $9,77 \pm 1,38$ & $8,505 \pm 1,22^{\mathrm{a}}$ \\
\hline Rata-rata & $6,493 \pm 1,49^{\mathrm{c}}$ & $7,598 \pm 0,86^{\mathrm{b}}$ & $8,250 \pm 1,58^{\mathrm{a}}$ & \\
\hline
\end{tabular}

Keterangan: Huruf yang berbeda di belakang nilai rata-rata rata pada baris atau kolom yang sama menunjukkan perbedaan nyata $(\mathrm{P} \leq 0,05)$. Data merupakan rata-rata dari dua kelompok percobaan.

Tabel 3 menunjukkan bahwa nilai rata-rata daya lekat tertinggi diperoleh pada perlakuan perbandingan 1:7. Pada suhu pemanasan, nilai rata-rata daya lekat tertinggi diperoleh pada perlakuan suhu $80 \pm 2^{\circ} \mathrm{C}$. Penelitian Natalie (2017) nilai daya lekat krim akan berbanding lurus dengan nilai viskositas krim. Semakin banyak jumlah lemak kakao dan semakin sedikit jumlah VCO nilai rata-rata daya lekat semakin meningkat. Hal ini dapat terjadi karena jumlah asam stearat yang mampu memadatkan sediaan krim.

Semakin besar suhu pemanasan pada proses pencampuran maka asam laurat yg terkandung pada VCO dan jumlah air akan menurun, sehingga pada perbandingan 1:7 dan pada suhu $80 \pm 2^{\circ} \mathrm{C}$ krim yang dihasilkan bersifat lebih padat. Krim yang baik memiliki daya lekat lebih dari 4 detik sehingga memaksimalkan efek adsorbsi zat aktif dan penetrasi krim ketika diaplikasikan pada kulit (Wasiaatmadja, 1997). 


\section{Daya Sebar}

Hasil analisis keragaman menunjukan perlakuan perbandingan fase minyak antara VCO dan lemak kakao, suhu pemanas dan interaksi kedua perlakuan berpengaruh sangat nyata $(\mathrm{p} \leq 0,01)$ terhadap daya sebar sediaan krim. Nilai rata-rata daya sebar dapat dilihat pada Tabel 4.

Tabel 4. Nilai rata-rata daya sebar $(\mathrm{cm})$ sediaan krim pada perlakuan perbandingan fase minyak VCO dan lemak kakao serta suhu.

\begin{tabular}{cccc}
\hline Perbandingan Bahan & \multicolumn{3}{c}{ Suhu $\left({ }^{\circ} \mathrm{C}\right)$} \\
\cline { 2 - 4 } (VCO\&Lemak Kakao) & $60 \pm 2$ & $70 \pm 2$ & $80 \pm 2$ \\
\hline$(1: 3)$ & $9,78 \pm 0,38^{\mathrm{a}}$ & $9,03 \pm, 46^{\mathrm{b}}$ & $8,18 \pm 0,17^{\mathrm{c}}$ \\
$(1: 5)$ & $7,96 \pm 0,14^{\mathrm{cd}}$ & $7,43 \pm 0,46^{\mathrm{de}}$ & $7,13 \pm 0,38^{\mathrm{e}}$ \\
$(1: 7)$ & $7,50 \pm 0,14 \mathrm{~d}^{\mathrm{e}}$ & $7,26 \pm 0,28^{\mathrm{e}}$ & $7,08 \pm 0,24^{\mathrm{e}}$ \\
\hline
\end{tabular}

Keterangan: Huruf yang berbeda di belakang nilai rata-rata menunjukkan adanya perbedaan yang sangat nyata ( $\mathrm{P} \leq 0,01)$. Data merupakan rata-rata dari dua kelompok percobaan.

Tabel 4 menunjukkan nilai uji daya sebar sediaan krim tertinggi diperoleh pada perlakuan perbandingan fase minyak 1:3 dengan suhu $60 \pm 2^{\circ} \mathrm{C}$. Meningkatnya nilai daya sebar dipengaruhi oleh banyaknya kandungan asam laurat pada VCO serta suhu pemanasan yang kecil. Menurut penelitian Lucida (2008) banyaknya kandungan asam laurat pada VCO $48 \%-53 \%$ yang bersifat cair pada suhu ruang, sedangkan menurut Risanti (2010) asam stearat pada lemak kakao bersifat padat pada suhu ruang. Peningkatan daya sebar juga dipengaruhi oleh lama waktu inkubasi selama 24 jam. Besaran suhu pada proses pemanasan dapat mempengaruhi sediaan krim yang dihasilkan, semakin kecil suhu pada proses pemanasan mengakibatkan nilai daya sebar meningkat karena tidak menguapnya air pada proses pencampuran bahan (Mitsuki, 1997). Menurut penelitian Erwiyani (2018) semakin encer sediaan krim maka diameter sebar sediaan krim akan melebar, karena daya sebar berbanding terbalik dengan viskositas krim. Daya sebar yang tinggi mengakibatkan adsorbsi bahan aktif ke kulit menjadi lebih baik, daya sebar sediaan krim yang baik dengan rentang 5-7 cm (Garh et al., 2001). Pengukuran daya sebar bertujuan untuk mengetahui kemampuan sediaan krim ketika diaplikasikan ke permukaan kulit.

\section{Rasio Pemisah}

Hasil analisis keragaman menunjukkan perlakuan perbandingan fase minyak lemak kakao dan VCO berpengaruh sangat nyata $(\mathrm{p} \leq 0,01)$ sedangkan suhu pemasan dan interaksinya tidak berpengaruh nyata $(\mathrm{p}>0,05)$ terhadap rasio pemisahan krim. Nilai rata-rata rasio pemisah pada sediaan krim dapat dilihat pada Tabel 5.

Tabel 5. Nilai rata-rata rasio pemisah sediaan krim pada perlakuan perbandingan fase minyak VCO dan lemak kakao serta suhu.

\begin{tabular}{ccccc}
\hline Perbandingan bahan & \multicolumn{4}{c}{ Suhu $\left({ }^{\circ} \mathrm{C}\right)$} \\
\cline { 2 - 5 }$($ VCO : Lemak Kakao) & $60 \pm 2$ & $70 \pm 2$ & $80 \pm 2$ & Rerata \\
\hline $1: 3$ & $0,79 \pm 0,02$ & $0,78 \pm 0,01$ & $0,76 \pm 0,02$ & $0,78 \pm 0,01^{\mathrm{a}}$ \\
$1: 5$ & $0,60 \pm 0,03$ & $0,53 \pm 0,01$ & $0,52 \pm 0,1$ & $0,55 \pm 0,04^{\mathrm{b}}$ \\
$1: 7$ & $0,47 \pm 0,02$ & $0,49 \pm 0,17$ & $0,27 \pm 0,01$ & $0,38 \pm 0,12^{\mathrm{c}}$ \\
\hline Rerata & $0,62 \pm 0,14^{\mathrm{a}}$ & $0,57 \pm 0,18^{\mathrm{a}}$ & $0,52 \pm 0,22^{\mathrm{a}}$ & \\
\hline
\end{tabular}

Keterangan: Huruf yang berbeda di belakang nilai rata-rata rata-rata pada baris dan kolom yang sama menunjukkan adanya perbedaan nyata $(\mathrm{p} \leq 0,01)$. Data merupakan rata-rata dari dua kelompok percobaan. 
Tabel 5 menunjukkan bahwa pemisahan krim tertinggi terjadi pada perlakuan perbandingan 1:3. Pemisahan terjadi diduga karena ada pengurangan asam stearat yang terkandung dalam lemak kakao, karena asam stearat berfungsi sebagai emulsifier yang dapat menstabilkan krim. krim yang tidak stabil karena adanya penurunan emulsifier, semakin sedikit emulsifier yang digunakan maka emulsi akan mudah mengalami koalesens sehingga membentuk suatu tetesan yang besar dan mengalami pemisahan. Emulsifier bekerja dengan membentuk lapisan (film) disekeliling tetesan terdispersi sehingga mencegah terjadinya koalesen dan terpisahnya cairan dispersi (Anief, 2008).

Pada suhu pencampuran yang rendah akan berdampak terjadinya pemisahan. Hal ini dikarenaan suhu tersebut baru menyentuh titik didih pada proses pembuatan dan tidak stabilnya emulsi dalam sediaan krim sehingga terjadinya pemisahan pada sediaan krim. Emulsi dikatakan baik jika $(F)=0$ atau mendekati 0 (Mollet and Grubenmann, 2001).

\section{Derajat Keasaman (pH)}

Hasil analisis keragaman menunjukkan perlakuan perbandingan bahan lemak kakao dan VCO serta suhu dan interaksinya tidak berpengaruh nyata $(\mathrm{p}>0,05)$ terhadap derajat keasaman $(\mathrm{pH})$ sediaan krim. Nilai rata-rata derajat keasaman $(\mathrm{pH})$ pada sediaan krim dapat dilihat pada Tabel 6 .

Tabel 6. Nilai rata-rata derajat keasaman $(\mathrm{pH})$ sediaan krim pada perlakuan perbandingan VCO dan lemak kakao serta suhu.

\begin{tabular}{ccccc}
\hline Perbandingan bahan & \multicolumn{4}{c}{ Suhu $\left({ }^{\circ} \mathrm{C}\right)$} \\
\cline { 2 - 5 }$($ VCO : Lemak Kakao) & $60 \pm 2$ & $70 \pm 2$ & $80 \pm 2$ & Rerata \\
\hline $1: 3$ & $5,60 \pm 0,84$ & $6,05 \pm 0,35$ & $6,25 \pm 0,07$ & $5,96 \pm 0,50^{\mathrm{a}}$ \\
$1: 5$ & $6,75 \pm 0,35$ & $6,15 \pm 0,21$ & $5,85 \pm 0,63$ & $6,25 \pm 0,53^{\mathrm{a}}$ \\
$1: 7$ & $6,65 \pm 0,49$ & $6,40 \pm 0,00$ & $6,65 \pm 0,21$ & $6,56 \pm 0,27^{\mathrm{a}}$ \\
\hline Rerata & $6,33 \pm 0,73^{\mathrm{a}}$ & $6,20 \pm 0,24^{\mathrm{a}}$ & $6,25 \pm 0,46^{\mathrm{a}}$ & \\
\hline
\end{tabular}

Keterangan: Huruf yang sama dibelakang nilai rata-rata rata-rata pada baris dan kolom yang sama menunjukan tidak adanya perbedaan nyata $(\mathrm{p}>0,05)$. Data merupakan rata-rata dari dua kelompok percobaan.

Tabel 6 menunjukkan bahwa perbandingan fase minyak VCO dan lemak kakao serta suhu tidak berbeda terhadap $\mathrm{pH}$ sediaan krim. Pada penelitian ini nilai $\mathrm{pH}$ rata-rata tertinggi pada perlakuan perbandingan VCO dan lemak kakao (1:7), tetapi tidak berbeda dengan perbandingan bahan VCO dan lemak kakao (1:3) dan (1:5). Pada perlakuan suhu didapatkan rata-rata tertinggi pada suhu $60 \pm 2^{\circ} \mathrm{C}$, tetapi tidak berbeda dengan perlakuan suhu $70 \pm 2^{\circ} \mathrm{C}$ dan $80 \pm 2^{\circ} \mathrm{C}$. Nilai $\mathrm{pH}$ dengan rentang 8 sampai 14 maka akan bersifat basa yang dapat mengakibatkan kulit terkelupas jika diaplikasikan pada kulit, sedangkan nilai $\mathrm{pH}$ yang sangat rendah dengan rentang nilai 1 sampai 4 bersifat asam dan mengakibatkan iritasi pada kulit jika diaplikasikan. Krim yang baik digunakan pada kulit adalah krim yang memiliki $\mathrm{pH}$ yang tidak terlalu jauh dari $\mathrm{pH}$ fisiologis kulit (Tranggono and Latifa, 2007). Hal ini sesuai dengan syarat mutu pelembab kulit yaitu SNI 16-4399-1996 nilai derajat keasaman $(\mathrm{pH})$ berkisar antara 4,5 sampai 7,5.

\section{Indeks Efektivitas}

Penentuan perlakuan terbaik dilakukan dengan uji indeks efektivitas untuk mengetahui perlakuan terbaik dalam pembuatan sediaan krim perbandingan fase minyak VCO dan lemak kakao serta pengaruh aplikasi suhu pemanasan. Perlakuan terbaik ditentukan berdasarkan 
hasil yang menunjukan nilai hasil tertinggi.

Tabel 7.

Hasil uji indeks efektivitas dapat dilihat pada

Tabel 7. Hasil Uji indeks efektivitas sedian krim pada perlakuan suhu dan perbandingan fase minyak VCO dan lemak kakao.

\begin{tabular}{|l|l|c|c|c|c|c|c|}
\hline \multirow{2}{*}{ Perlakuan } & \multicolumn{9}{|c|}{ Variabel } \\
\cline { 2 - 8 } & & Viskositas & Daya lekat & $\begin{array}{c}\text { Daya } \\
\text { sebar }\end{array}$ & $\begin{array}{c}\text { Rasio } \\
\text { pemisah }\end{array}$ & $\begin{array}{c}\text { Derajat } \\
\text { Keasaman }\end{array}$ & Jumlah \\
\hline & $(\mathrm{BV})$ & 4,20 & 4,20 & 3,20 & 3,20 & 3,20 & 18,00 \\
\cline { 2 - 8 } & $\mathrm{BN})$ & 0,23 & 0,23 & 0,18 & 0,18 & 0,18 & 1,00 \\
\hline B1T1 & $\mathrm{Ne}$ & 0,00 & 0,00 & 0,00 & 0,00 & 0,00 & \\
\hline & $\mathrm{Nh}$ & 0,00 & 0,00 & 0,00 & 0,00 & 0,00 & 0,00 \\
\hline B1T2 & $\mathrm{Ne}$ & 0,43 & 0,37 & 0,68 & 0,01 & 0,39 & \\
\hline & $\mathrm{Nh}$ & 0,10 & 0,09 & 0,12 & 0,00 & 0,07 & 0,38 \\
\hline B1T3 & $\mathrm{Ne}$ & 0,71 & 0,37 & 0,84 & 0,04 & 0,57 & \\
\hline & $\mathrm{Nh}$ & 0,17 & 0,09 & 0,15 & 0,01 & 0,10 & 0,51 \\
\hline B2T1 & $\mathrm{Ne}$ & 0,14 & 0,54 & 0,28 & 0,37 & 1,00 & \\
\hline & $\mathrm{Nh}$ & 0,03 & 0,13 & 0,05 & 0,06 & 0,18 & 0,45 \\
\hline B2T2 & $\mathrm{Ne}$ & 0,43 & 0,66 & 0,87 & 0,50 & 0,48 & \\
\hline & $\mathrm{Nh}$ & 0,10 & 0,15 & 0,15 & 0,09 & 0,09 & 0,58 \\
\hline B2T3 & $\mathrm{Ne}$ & 0,71 & 0,75 & 0,94 & 0,50 & 0,22 & \\
\hline & $\mathrm{Nh}$ & 0,17 & 0,17 & 0,17 & 0,09 & 0,04 & 0,63 \\
\hline B3T1 & $\mathrm{Ne}$ & 0,43 & 0,55 & 0,59 & 0,62 & 0,91 & \\
\hline & $\mathrm{Nh}$ & 0,10 & 0,13 & 0,11 & 0,11 & 0,16 & 0,61 \\
\hline B3T2 & $\mathrm{Ne}$ & 0,57 & 0,71 & 0,98 & 0,71 & 0,70 & \\
\hline & $\mathrm{Nh}$ & 0,13 & 0,17 & 0,17 & 0,13 & 0,12 & 0,73 \\
\hline B3T3 & $\mathrm{Ne}$ & 1,00 & 1,00 & 1,00 & 0,99 & 0,91 & \\
\hline & $\mathrm{Nh}$ & 0,23 & 0,23 & 0,18 & 0,18 & 0,16 & $\mathbf{0 , 9 8}$ \\
\hline
\end{tabular}

Keterangan : $\mathrm{Ne}=$ nilai efektivitas

$\mathrm{Nh}=$ nilai hasil $(\mathrm{Ne} \times \mathrm{BN})$

Tabel 7 menunjukkan bahwa nilai tertinggi diperoleh pada perlakuan perbandingan VCO dan lemak kakao 1:7 dan suhu $80 \pm 2^{\circ} \mathrm{C}$ yaitu 0,98 yang berarti perlakuan tersebut merupakan perlakuan terbaik dibandingkan dengan perlakuan yang lain dalam terbentuknya sediaan krim.

\section{KESIMPULAN DAN SARAN}

\section{Kesimpulan}

Berdasarkan penelitian yang telah dilakukan dapat disimpulkan hal-hal berkut:

1. Perlakuan perbandingan fase minyak VCO dan lemak kakao berpengaruh sangat nyata terhadap viskositas, daya
$\mathrm{BV}=$ bobot variabel

$\mathrm{BN}=$ bobot normal

lekat, daya sebar dan rasio pemisah. Suhu pemanasan berpengaruh sangat nyata sangat nyata terhadap daya sebar dan daya lekat. Interaksi perlakuan perbandingan fase minyak dan suhu berpengaruh sangat nyata terhadap daya sebar.

2. Perlakuan dengan suhu pemanasan $80 \pm 2^{\circ} \mathrm{C}$ dan perbandingan fase minyak antara VCO dan lemak kakao 1 : 7 merupakan perlakuan terbaik untuk menghasilkan sediaan krim terbaik dengan karakteristik krim bersifat homogen, viskositas (46.000 cp), daya lekat $(9,77$ detik), daya sebar $(7,075 \mathrm{~cm})$, rasio pemisah $(0,27 \mathrm{~cm})$ dan $\mathrm{pH}(6,65)$. 


\section{Saran}

Berdasarkan hasil penelitian, disarankan menggunakan perbandingan fase minyak (VCO dan lemak kakao $1: 7$ ) dengan suhu pemanasan saat proses pembuatan sebesar $80 \pm 2^{\circ} \mathrm{C}$ untuk menghasilkan sediaan krim serta dilakukannya penelitian lebih lanjut mengenai perlakuan penambahan pengemulsi dan bahan aktif pada sediaan krim.

\section{DAFTAR PUSTAKA}

Allen, I.V. 2002. The Art, Science and Technology of Pharmaceutical Compounding. Second Edition. American Pharmaceutycal Assosiation, Washington DC.

Anief, M. 2004. Ilmu Meracik Obat, Teori dan Praktik. Gadjah Mada University Press, Yogyakarta.

Anwar, 2012. Eksipien Dalam Sediaan Farmasi Karakterisasi dan Aplikasi. Penerbit Dian Rakyat, Jakarta.

Badan Standarisasi Nasional. 1996. Sediaan Tabir Surya. Standar Nasional Indonesia, Jakarta.

de Garmo, E.P., W.G. Sullivan, and C.R. Canada. 1984. Engineering Economy. Macmillan Publisher, New York.

Delia, K.S., N. Sugihartini, and T. Yuwono. 2015. Evaluasi uji iritasi dan uji sifat fisik sediaan emulgel minyak atsiri bunga cengkeh. Jurnal Farmasi. 5(2): 115-120.

Diah, S., and D.I. Sari. 2014. Pengaruh konsentrasi asam stearat terhadap karakteristik sediaan dan pelepasan krim kurkumin. Jurnal Pharmascience. 1(1): 14-17

Dwiastuti, R. 2009. Optimasi Proses Pembuatan Krim Sunscreen Ekstrak Kering Polifenol Teh Hijau (Camelia sinennsis L.) Dengan Metode Desain Faktorial. Skripsi. Tidak dipublikasikan. Universitas Gadjah Mada, Yogyakarta.

Erwiyani, A.R., D. Destianti, and S.A. Kabalen. 2018. Pengaruh lama penyimpanan terhadap sediaan fisik krim daun alpukat (Persen americana M.) dan daun sirih (Piper bettle L.). Indonesian Journal of Pharmacy and Naturnal Product. 1(1) : 26-27.

Garg, A., D. Aggarwal, S. Garg, and A.K. Singla. 2002. Spreading of semisolid formulation. Pharmaceutical Technology. 1(1):84-102

Iswindari, D. 2014. Formulasi dan Uji Antioksidan Krim Rice Bran Oil. Skripsi. Tidak dipublikasikan. UIN Syarif Hidayatullah, Jakarta.

Lestari, T. 2002. Hand and Body Lotion: Pengaruh Penambahan Nipagin Nipasol dan Campuran Keduanya Terhadap Stabilitas Fisika dan Efektifitasnya sebagai Anti Jamur. Skripsi. Tidak dipublikasikan. Fakultas Farmasi Universitas Gadjah Mada, Yogyakarta.

Lucida, H., Salman and M.S. Hervian. 2008. Uji daya peningkat penetrasi virgin coconut oil dalam basis krim. Jurnal Sains dan Teknologi Farmasi. 1(13): 78-112.

Michael and I. Ash. 1997. A Formulary of Cosmetic Preparation. Chemical Publishing Co., New York.

Mitsuki, T. 1997. New Cosmetic Science. Shiseido Co.Ltd, Tokyo.

Mollet, H and Grubenmann. 2001. Formulation Technology: Emulsion, Suspensions, Solid Forms

. Wiley-VCH Verlag, German. 
Mu'awanah, I.A.U., B. Setiaji, and A. Syoufian. 2014. Pengaruh konsentrasi virgin coconout oil terhadap stabilitas emulsi kosmetik dan nilai sun protection factor. Berkala MIPA. 24(1):3-5.

Natalie, A., S. Mulyani., and B.A, Harsujuwono. 2017. Hubungan lama simpan dengan karakteristik mutu pada berbagai formulasi krim ekstrak kunyit (Curcuma dosmeticate V.). Jurnal Rekayasa dan Manajemen Agroindustri. 5 : 21-30.

Nayank, S.H., P.D. Nkhat, and P.G. Yeole. 2004. Comparison of epidermal hydration and skin surface lipids in healthy individuals and in patients with atopic dermatitis. The Indian Pharmacist. 27(3): 7-14.

Nielloud, F., and G.M. Mesters. 2000. Experimental Methods Applied to Real Cases. In Pharmaceuticals Emulsions and Suspensions. J.L. Salager (Ed). Marcell Dekker Inc., New York. p. 561-590.
Novilla, A., and P. Nursidika. 2017. Komposisi asam lemak minyak kelapa murni yang berpotensi sebagai anti kandidasis. Jurnal Kimia dan Pendidikan. 2(2): 161-173.

Rubiyo dan Widiamara. 2013. Ketahanan Tanaman Kakao Terhadap Penyakit Busuk Buah (Phytopthora palmivora B.). Pusat Penelitian dan Pengembangan Perkebunan, Bogor.

Setiaji, B and P. Surip. 2006. Membuat VCO Berkualitas Tinggi. Penerbit Penebar Swadaya, Jakarta.

Smaoui, S., H.B. Hilma, R. Jarraya, N.G. Komoun, R. Ellouze, and M. Damak. 2012. Cosmetic emulsion of virgin coconut oil : formulation and biophysical evaluation. African Journal of Biotechnology. 11(34):8417-8424.

Tranggono, R. I., and F. Latifah. 2007. Buku Pegangan Ilmu Pengetahuan Kosmetik. PT. Gramedia, Jakarta.

Wasiaatmadja, S.M. 2007. Penuntun Ilmu Kosmetik Medik. UI Press, Jakarta. 


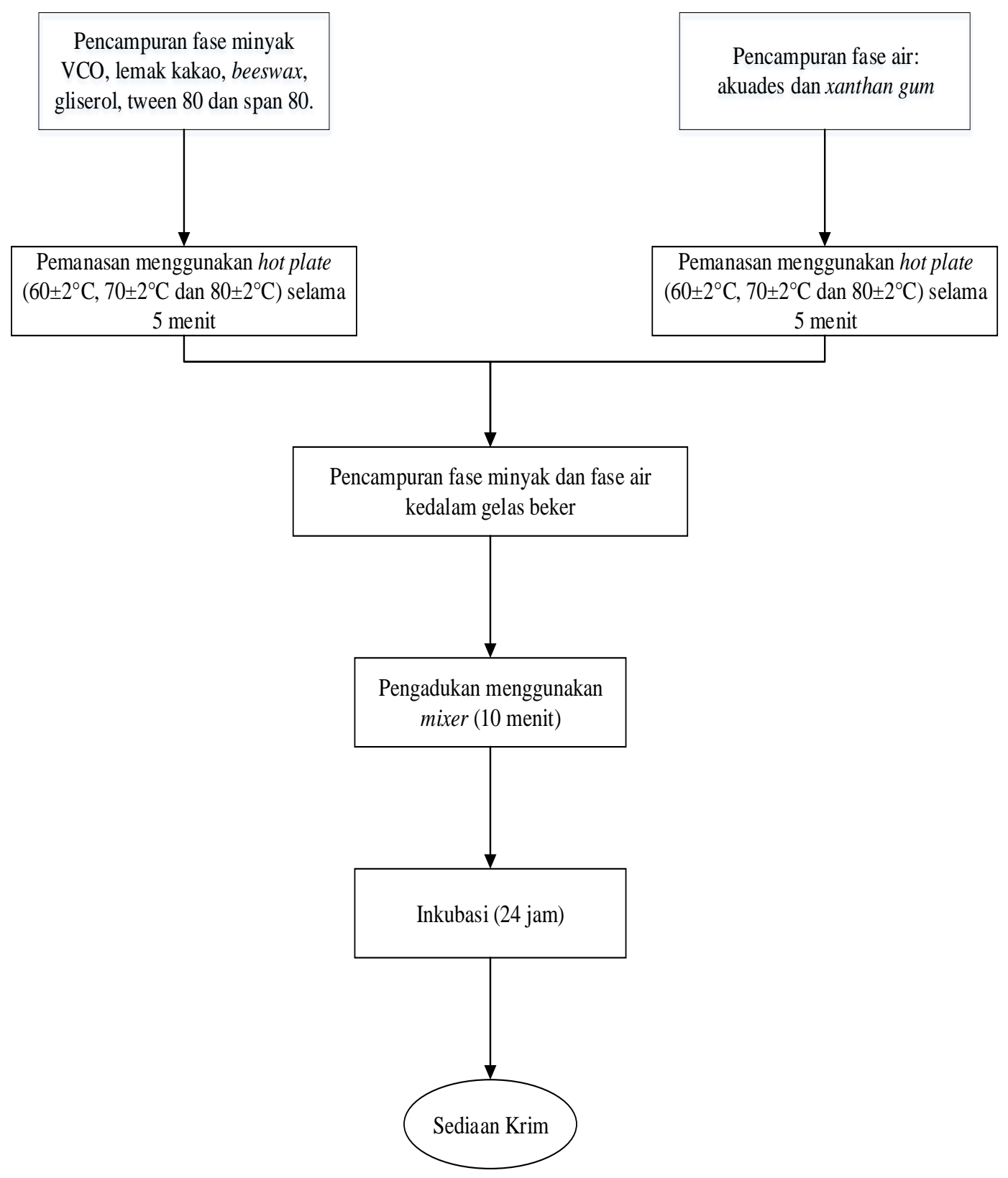

Gambar 1. Diagram alir pembuatan sediaan krim (Kusumowardani, 2010) dengan modifikasi 